\title{
Programmable Logic Controller (PLC) Based Paint Viscosity Control System
}

\section{Sistem Kendali Viskositas Cat Berbasis Programmable Logic Controller (PLC)}

\author{
Gema Ridho Wicaksono, Riky Dwi Puriyanto
}

Program Studi Teknik Elektro, Universitas Ahmad Dahlan, Indonesia

\section{INFORMASI ARTIKEL}

\section{Riwayat Artikel:}

Dikirimkan 24 September 2019, Direvisi 23 November 2019, Diterima 03 Januari 2021.

\section{Kata Kunci:}

PLC,

Viskositas,

Kendali Suhu,

LM35DZ,

CX-Programmer.

\section{Penulis Korespondensi:}

Riky Dwi Puriyanto, Teknik Elektro, Universitas Ahmad Dahlan,

Kampus IV, Jl.Ring Road

Selatan, Tamanan,

Banguntapan, Bantul

Yogyakarta 55166.

Surel/Email:

rikydp@ee.uad.ac.id

\section{ABSTRACT / ABSTRAK}

Automatic control has been developed in various fields, one of which is paint quality control. Paint quality can be controlled from various categories, including paint quality based on its viscosity. Therefore, we need a system that can control the viscosity of paint. The paint viscosity control system uses the PLC OMRON CP1E-NA2ODRA with a heater as a heat source, and the $L M 35 D Z$ sensor as a temperature reading sensor and the RPM reading is used to calculate the viscosity value. The programming language used is the ladder diagram on the CX-Programmer. This system uses the PID (Proportional, Integral, and Derivative) Algorithm so that temperature control can be set at $30^{\circ} \mathrm{C}$ so as not to affect the viscosity of the paint. In addition, this prototype provides two PID tuning options, namely manual and auto tuning. Researchers get the results that a good temperature control system response has a $P B$ value $=0.2 \% ; T i=452.5 \mathrm{~s}$ and $T D=66.6 \mathrm{~s}$. and control accuracy level of paint viscosity control of $67.82 \%$.

Pengendalian otomatis dikembangkan di berbagai bidang, salah satunya yaitu kendali kualitas cat. Kualitas cat dapat dikendalikan dari berbagai kategori, di antaranya yaitu kualitas cat berdasarkan viskositasnya. Oleh karena itu diperlukannya suatu sistem yang dapat mengendalikan viskositas cat. Sistem kendali viskositas cat menggunakan PLC OMRON CP1E-NA20DRA dengan heater sebagai sumber panas, serta sensor LM35DZ sebagai sensor pembaca suhu serta pembacaan RPM digunakan untuk menghitung nilai viskositas. Bahasa pemrograman yang digunakan yaitu ladder diagram pada CXProgrammer. Sistem ini menggunakan Algoritma PID (Proportional, Integral, and Derivative) agar kontrol suhu dapat diatur pada suhu $30^{\circ} \mathrm{C}$ supaya tidak mempengaruhi viskositas cat. Selain itu purwarupa ini menyediakan dua pilihan penalaan PID yaitu manual dan autotuning. Peneliti memperoleh hasil bahwa respon sistem kendali suhu yang baik memiliki nilai $\mathrm{PB}=0,2 \%$; $\mathrm{Ti}=$ $452,5 \mathrm{~s}$ dan $\mathrm{TD}=66,6 \mathrm{~s}$. dan tingkat akurasi kendali pengendalian viskositas cat sebesar $67,82 \%$.

This work is licensed under a Creative Commons Attribution-Share Alike 4.0

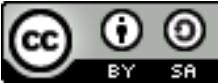

\section{Sitasi Dokumen ini:}

G. R. Wicaksono and R. D. Puriyanto, "Programmable Logic Controller (PLC) Based Paint Viscosity Control System," Buletin Ilmiah Sarjana Teknik Elektro, vol. 3, no. 1, pp. 1-9, 2021. DOI: 10.12928/biste.v3i1.1109 


\section{PENDAHULUAN}

Cat adalah suatu cairan yang dipakai untuk melapisi permukaan suatu bahan dengan tujuan memperindah (decorative), memperkuat (reinforcing) atau melindungi (protective) bahan tersebut. Adapun beberapa cara untuk melekatkan cat tersebut ke permukaan yaitu cara diusapkan (wiping), dilumurkan, disemprotkan (spray), dicelupkan (dipping) ataupun dengan cara yang lain. Salah satu faktor penentu kualitas pengecatan adalah proses pencampuran bahan baku cat utama dengan bahan tambahan lainnya dengan perbandingan yang tepat. Bahan tambahan yang dipakai menyesuaikan dengan teknik pengecatan yang akan digunakan dan permukaannya. Bahan tambahan yang dipakai untuk menentukan tingkat kekentalan (viskositas) cat tersebut adalah thinner [1].

Perbandingan campuran cat dengan thinner yang tidak tepat dapat menyebabkan tingkat viskositas tidak sesuai kebutuhan (terlalu encer ataupun terlalu kental) yang akan berpengaruh terhadap proses pelapisan cat yaitu tingkat kekilapan cat [2]. Masalah pencampuran cat ini terkadang dianggap masalah yang sepele di kalangan masyarakat, tetapi tanpa mengetahui dampak yang besar terhadap kualitas cat tersebut. Berkat teknologi dan ilmu pengetahuan yang semakin berkembang maka didapatkan sebuah solusi dengan membuat sebuah alat yang dapat mencampur maupun mengendalikan tingkat viskositas yang tepat antara cat dengan bahan tambahan lainnya. Hal ini dapat diketahui dengan menggunakan prinsip pengukuran viskositas dengan metode pembacaan rpm yang akan diubah menjadi nilai viskositas [1][3].

Selain viskositas, suhu yang baik dalam pencampuran cat yaitu $30^{\circ} \mathrm{C}$ [4]. Kendali suhu beserta viskositas dapat dipermudah menggunakan alat elektronik berupa mikrokontroller atau PLC. Pada Penelitian ini pengolahan data menggunakan alat elektronik berupa PLC (Programmable Logic Controller).

PLC (Programmable Logic Controller) adalah sebuah alat yang digunakan untuk menggantikan rangkaian sederetan relay yang ada pada sistem kendali konvensional. PLC bekerja dengan cara mengamati masukan (melalui sensor), kemudian melakukan proses dan melakukan tindakan sesuai yang dibutuhkan, berupa menghidupkan atau mematikan keluaran. Program yang digunakan adalah berupa ladder diagram yang kemudian harus dijalankan oleh PLC [5][6][7].

Tujuan penelitian ini adalah membuat suatu sistem kendali viskositas dalam pencampuran cat dengan bahan tambahan lainnya menggunakan PLC secara otomatis dengan deskripsi berikut :

1. Membuat purwarupa/Prototipe sistem kendali viskositas cat berbasis PLC,

2. Mengimplementasikan PID pada sensor suhu LM35DZ untuk mendapatkan suhu $30^{\circ} \mathrm{C}$,

3. Membuat HMI untuk menampilkan nilai viskositas serta suhu yang diinginkan.

\section{METODE PENELITIAN}

Penelitian sistem kendali viskositas cat berbasis PLC ditunjukkan diagram alir pada Gambar 1. Berdasarkan Gambar 1. sistem bekerja secara berurutan. Proses awal yang dilakukan yaitu inisialisasi yang akan dilanjutkan proses penuangan bahan ke dalam tangki dengan membuka pompa cat dan thinner yang kemudian dibaca nilai viskositasnya. Apabila nilai viskositas lebih dari nilai set point maka pompa thinner akan terbuka dan pompa cat tertutup, begitu pun sebaliknya dan apabila nilai viskositas sesuai dengan set point maka motor DC pengaduk akan Berhenti.

Adapun nilai viskositas yang akan diatur dalam Penelitian ini yaitu 7,62 CP (centipoise). Metode pembacaan kecepatan putar motor dapat dihitung dengan persamaan 1.

$$
\text { viskositas }=1,7711 \mathrm{x} \text { rotasi putaran }-232,22
$$

Persamaan 1 kemudian diubah dalam bentuk bahasa ladder diagram, setelah pengolahan yang dilakukan untuk mendapatkan nilai viskositas $(\mathrm{cP})$ maka proses selanjutnya yaitu menyesuaikan nilai viskositas terbaca dengan nilai viskositas setpoint yang sudah ditetapkan. Proses ini dapat dioperasikan dalam bahasa ladder dengan menggunakan fungsi comparator (perbandingan). Kalibrasi yang dilakukan pada sistem ini yaitu membandingkan suatu cairan dengan nilai baku suatu cairan lain. Nilai baku cairan ditunjukkan pada Tabel 1.

Tabel 1. Nilai viskositas

\begin{tabular}{ccc}
\hline No & Cairan & Viskositas $(\mathbf{P})$ \\
\hline 1 & Akuades & $9.6 \times 10^{-4}$ \\
\hline 2 & Alkohol & $1,47 \times 10^{-3}$ \\
\hline 3 & Air & $7,96 \times 10^{-4}$ \\
\hline 4 & Aseton & $5,11 \times 10^{-4}$ \\
\hline 5 & Santan Kara & $3,79 \times 10^{-4}$ \\
\hline
\end{tabular}


Adapun rangkaian perangkat keras ditunjukkan pada Gambar 2. Berdasarkan diagram blok pusat sistem yaitu PLC sebagai pusat kendali. Sistem ini menggunakan MIMO(Multi Input Multi Output) dalam menjalankan program, deskripsi input dan output pada PLC ditunjukkan tabel 2.

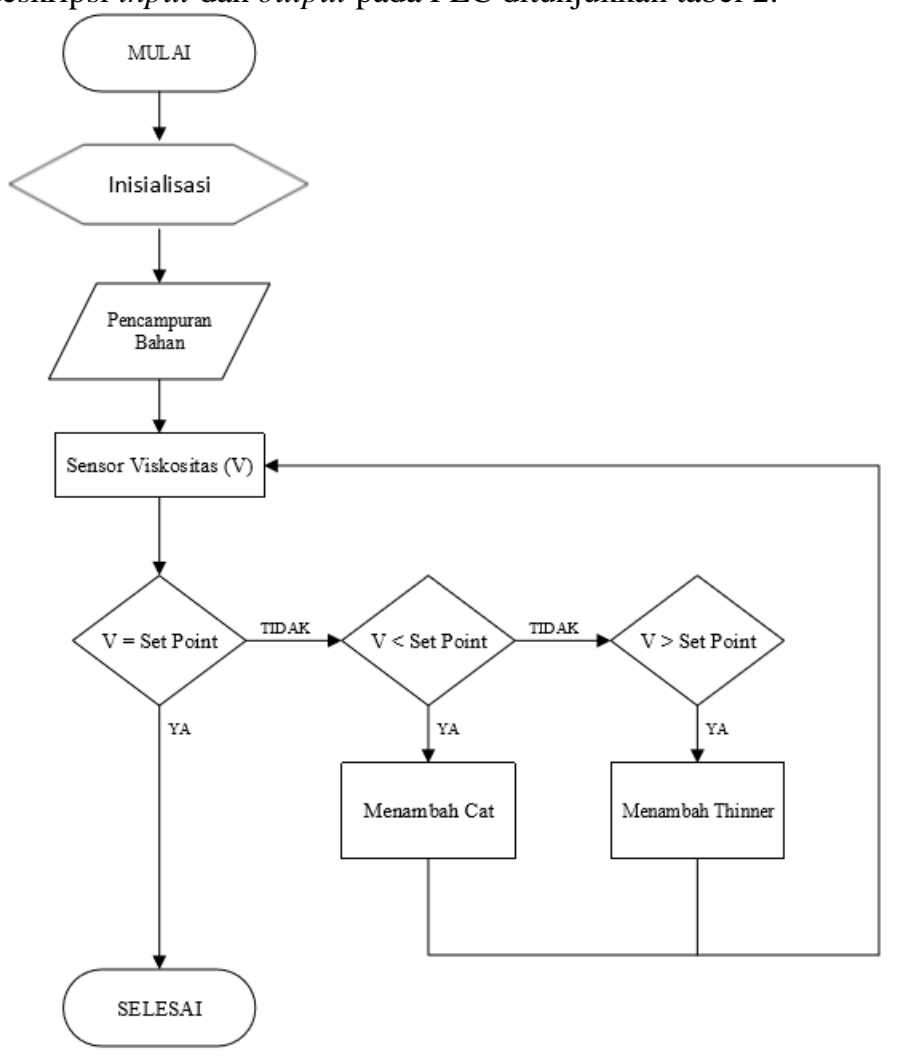

Gambar 1. Diagram alir sistem

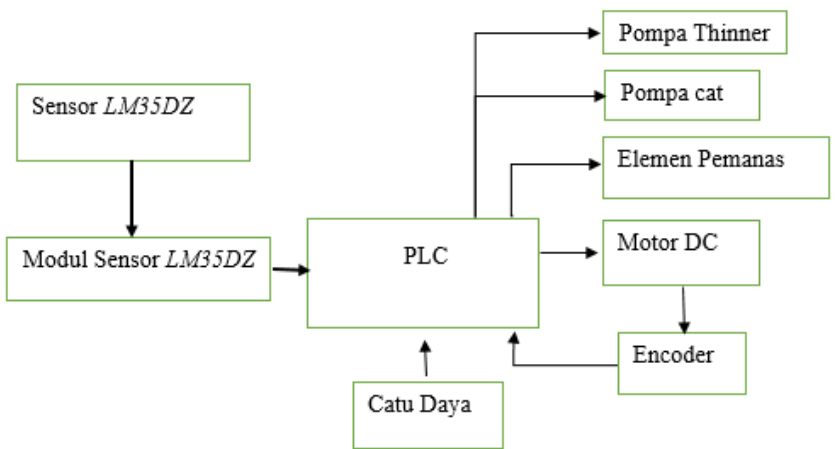

Gambar 2. Diagram blok sistem

Tabel 2. Input dan output pada PLC

\begin{tabular}{ccc}
\hline No & Input & Output \\
\cline { 1 - 2 } 1 & Sensor LM35DZ & Elemen pemanas \\
\cline { 2 - 3 } 2 & Modul sensor LM35DZ & Pompa thinner \\
\cline { 2 - 3 } 2 & Motor DC + encoder & dan pompa cat \\
\hline
\end{tabular}

Sensor LM35DZ memerlukan modul LM35 DZ supaya sensor dapat menyesuaikan keluaran analog pin PLC. Modul LM35DZ yaitu modul untuk menguatkan sinyal dari sensor LM35DZ menjadi 10 kali lipat dari spesifikasi sensor LM35DZ. Sensor LM35DZ memiliki keluaran $10 \mathrm{mV} /{ }^{\circ} \mathrm{C}$, kemudian dikuatkan modul $\mathrm{LM} 35 \mathrm{DZ}$ menjadi $100 \mathrm{mV} /{ }^{\circ} \mathrm{C}$ untuk menyesuaikan keluaran input analog sebesar 10VDC [8]. Rentang suhu 
yang dibaca sensor sesuai dengan modul dan analog input yaitu $10 \mathrm{~V} /{ }^{\circ} \mathrm{C}$. Rangkaian skematik modul LM35DZ ditunjukkan Gambar 3.

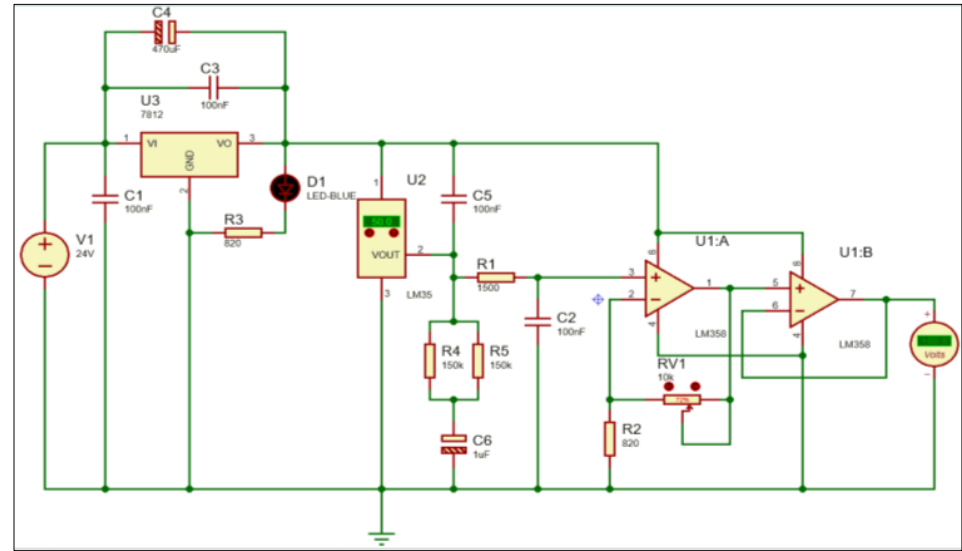

Gambar 3. Rangkaian skematik modul LM35DZ

Nilai tegangan keluaran modul diubah oleh ADC dari PLC dan dilakukan penskalaan dengan rumus penskalaan sebagai berikut [9]:

$$
\text { Suhu }=X \frac{\text { range input }}{\text { resolusi } \times \text { linearitas }}
$$

Dengan $X$ adalah nilai analog yang dibaca di CIO 91, Range input $=10(0-10 \mathrm{~V})$, Resolusi $=6000$, Linearitas $=0,1 \mathrm{~V} /{ }^{\circ} \mathrm{C}$ Tabel 3.

Diagram pengkabelan sistem ditunjukkan pada Gambar 4 dan Penjelasan pin I/O ditunjukkan pada

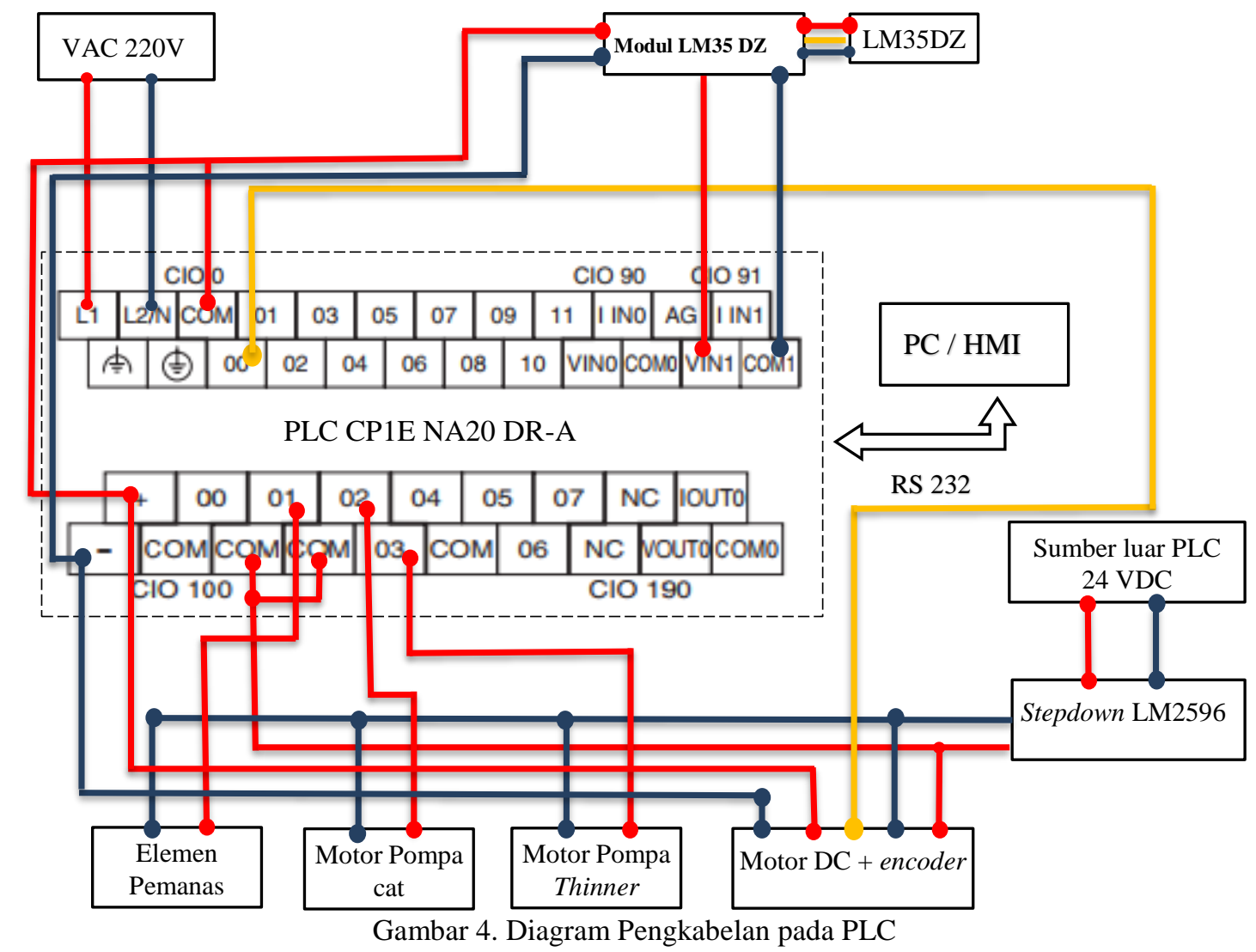

Ket :

$=-/$ Netral $=$ Data $=+/$ Fasa 
Tabel 3. Pin $I / O$ yang digunakan pada PLC

\begin{tabular}{|c|c|c|c|}
\hline NO & Komponen & Alamat & Keterangan \\
\hline \multirow{4}{*}{1} & \multirow{4}{*}{ Modul LM35DZ } & $+/ 24$ VDC PLC & Masukan VCC modul LM35DZ \\
\hline & & -/ Netral PLC & Masukan netral modul LM35DZ \\
\hline & & CIO 91 VIN 1 & Keluaran VCC pada modul LM35DZ \\
\hline & & CIO $91 \mathrm{COM} 1$ & Keluaran netral pada modul LM35DZ \\
\hline \multirow[b]{2}{*}{2} & \multirow[b]{2}{*}{ Elemen pemanas } & CIO 100.01 & Keluaran PLC VCC \\
\hline & & - & $\begin{array}{l}\text { Pin netral elemen pemanas sambungkan } \\
\text { dengan netral stepdown }\end{array}$ \\
\hline \multirow[b]{2}{*}{3} & \multirow[b]{2}{*}{ Motor pompa cat } & CIO 100.02 & Keluaran PLC VCC \\
\hline & & - & $\begin{array}{c}\text { Pin netral motor pompa cat sambungkan } \\
\text { dengan netral stepdown }\end{array}$ \\
\hline \multirow[t]{2}{*}{4} & Motor pompa thinner & CIO 100.03 & Keluaran PLC VCC \\
\hline & & 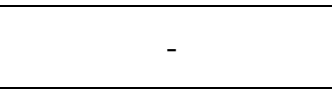 & $\begin{array}{l}\text { Pin netral motor pompa cat sambungkan } \\
\text { dengan netral stepdown }\end{array}$ \\
\hline \multirow{4}{*}{5} & \multirow{4}{*}{ Motor DC + encoder } & $+/ 24$ VDC PLC & Masukan VCC \\
\hline & & -/ Netral PLC & Masukan netral \\
\hline & & CIO 0.00 & Masukan data sensor encoder pada PLC \\
\hline & & COM CIO $0.00-0.11$ & $\begin{array}{l}\text { Memberikan tegangan } 12 \text { VDC pada } \\
\text { masukan PLC alamat tsb }\end{array}$ \\
\hline 6 & Stepdown LM2596 & $\begin{array}{c}\text { COM CIO 100.01 } \\
\text { COM CIO 100.02 } \\
\text { dan } 100.03\end{array}$ & $\begin{array}{l}\text { Memberikan tegangan } 12 \text { VDC pada } \\
\text { keluaran PLC alamat tsb }\end{array}$ \\
\hline
\end{tabular}

\section{HASIL DAN PEMBAHASAN}

Pembahasan yang akan dilakukan yaitu pembahasan/pengujian dengan perangkat keras maupun perangkat lunak.

\subsection{Pengujian Modul LM35DZ}

Pengujian dilakukan dengan mengamati apakah suhu yang terbaca pada sensor LM35DZ sama dengan termometer. Pengujian dilakukan dimulai dari suhu $27^{\circ} \mathrm{C}-30^{\circ} \mathrm{C}$ dengan mengamati tegangan keluaran. Hasil pengujian ditunjukkan pada Tabel 4.

Tabel 4. Pengujian modul LM35DZ

\begin{tabular}{ccccc}
\hline No & Suhu $\left({ }^{\mathbf{0}} \mathbf{C}\right)$ & Tegangan $(\mathbf{V})$ & Termometer $\left({ }^{\mathbf{0}} \mathbf{C}\right)$ & Selisih \\
\hline 1 & 27 & 2,7 & 27 & 0 \\
\hline 2 & 27,2 & 2,72 & 27,3 & 0,1 \\
\hline 3 & 27,7 & 2,77 & 27,7 & 0 \\
\hline 4 & 28,2 & 2,82 & 28,1 & 0,1 \\
\hline 5 & 28,4 & 2,84 & 28,3 & 0,1 \\
\hline 6 & 28,8 & 2,88 & 28,7 & 0,2 \\
\hline 7 & 29,2 & 2,90 & 29,0 & 0,2 \\
\hline 8 & 29,4 & 2,94 & 29,2 & 0,4 \\
\hline 9 & 29,7 & 2,97 & 29,3 & 0,4 \\
\hline 10 & 29,9 & 2,99 & 29,5 & 0,2 \\
\hline 11 & 30,1 & 3,01 & 29,9 & 0,3 \\
\hline 12 & 30,3 & 3,03 & 30,0 & 2,1 \\
\hline$\sum$ & Jumlah & & & $2,1 / 12=0,175$ \\
\hline
\end{tabular}

Berdasarkan Tabel 4 sensor suhu berjalan dengan baik dengan tingkat error $\pm 0,175^{\circ} \mathrm{C}$, tetapi dalam pengujian yang lain semakin lama sensor hidup maka sensor semakin jauh dari termometer dengan rentang di bawah $1^{\circ} \mathrm{C}$. Sedangkan hubungan antara suhu dan tegangan menunjukkan bahwa penskalaan 10x lipat berjalan dengan baik. 


\subsection{Pengujian Kendali Suhu}

Pengujian kendali suhu dilakukan dengan metode PID yang dilakukan dengan cara tuning maupun autotuning.

\subsubsection{Pengujian Secara Autotuning}

Pengujian proses autotuning dilakukan dengan setpoint $30^{\circ} \mathrm{C}$ dengan cara mengaktifkan mode autotuning dengan memberi nilai sampling $=0,5 \mathrm{~s}$. Hasil penalaan secara autotuning didapatkan nilai Proportional Band $(\mathrm{PB})=0,3 \%$; Integral Constant $(\mathrm{Ti})=457,7 \mathrm{~s}$ dan Derrivative Constant $(\mathrm{TD})=68,7 \mathrm{~s}$. Didapatkan nilai Rise Time $(\mathrm{TR})=12$ menit; Peak Time $(\mathrm{TP})=13,5$ menit; nilai $\max$ overshoot $=0,3{ }^{\circ} \mathrm{C}$. Hasil penalaan secara autotuning ditunjukkan Gambar 5.

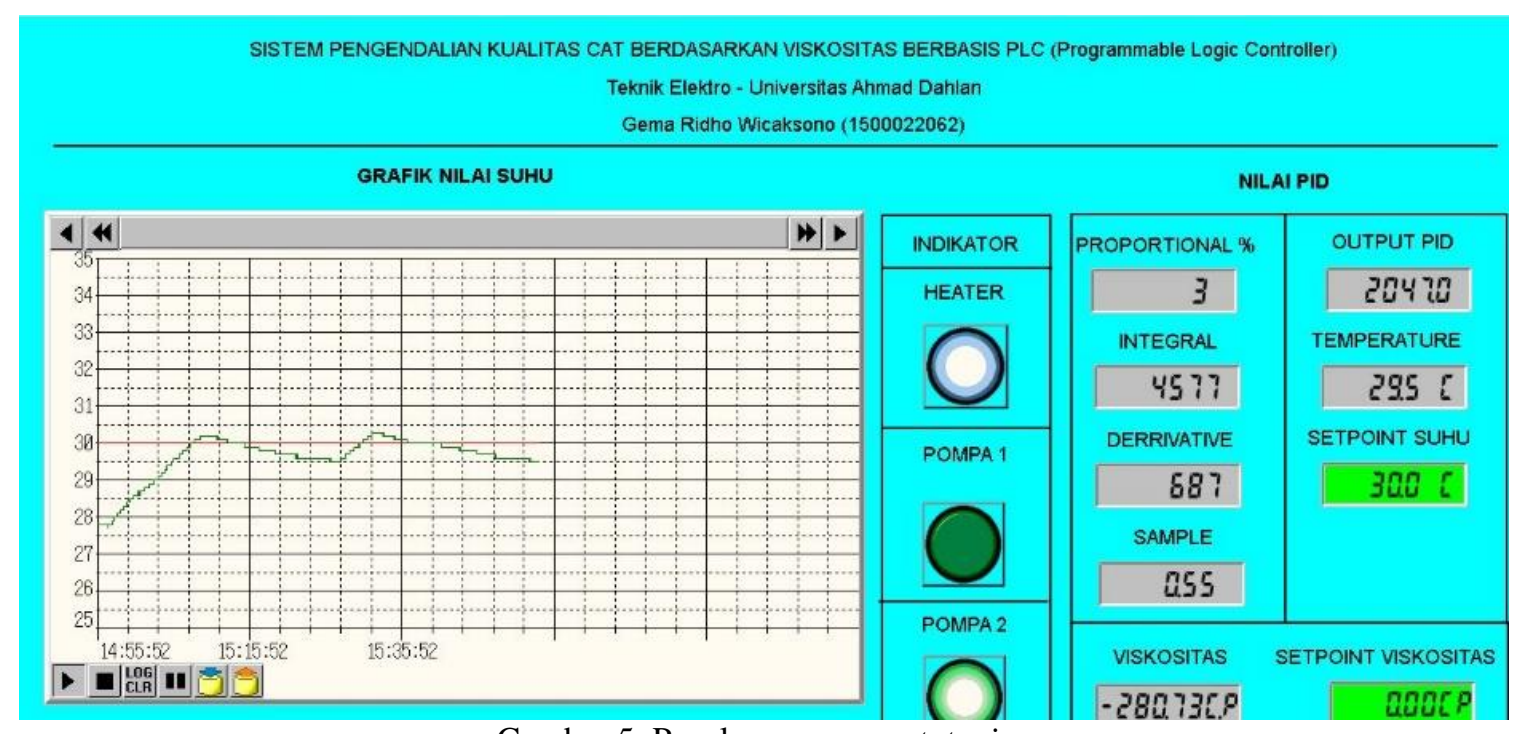

Gambar 5. Penalaan secara autotuning

\subsubsection{Pengaruh Perubahan Nilai PID}

Pengujian proses tuning pertama dilakukan dengan setpoint $30^{\circ} \mathrm{C}$ dengan memberi nilai sampling $=$ 0,5 s. Proses penalaan dengan nilai (Proportional Band) $\mathrm{PB}=0,3 \%$; (Integral Constant) $\mathrm{Ti}=52,6 \mathrm{~s}$ dan (Derrivative Constant) TD $=66 \mathrm{~s}$. Maka didapatkan nilai Rise Time $(\mathrm{TR})=12$ menit; Peak Time $(\mathrm{TP})=16$ menit; dengan nilai max overshoot $=0,4^{\circ} \mathrm{C}$. Hasil penalaan secara autotuning ditunjukkan Gambar 6

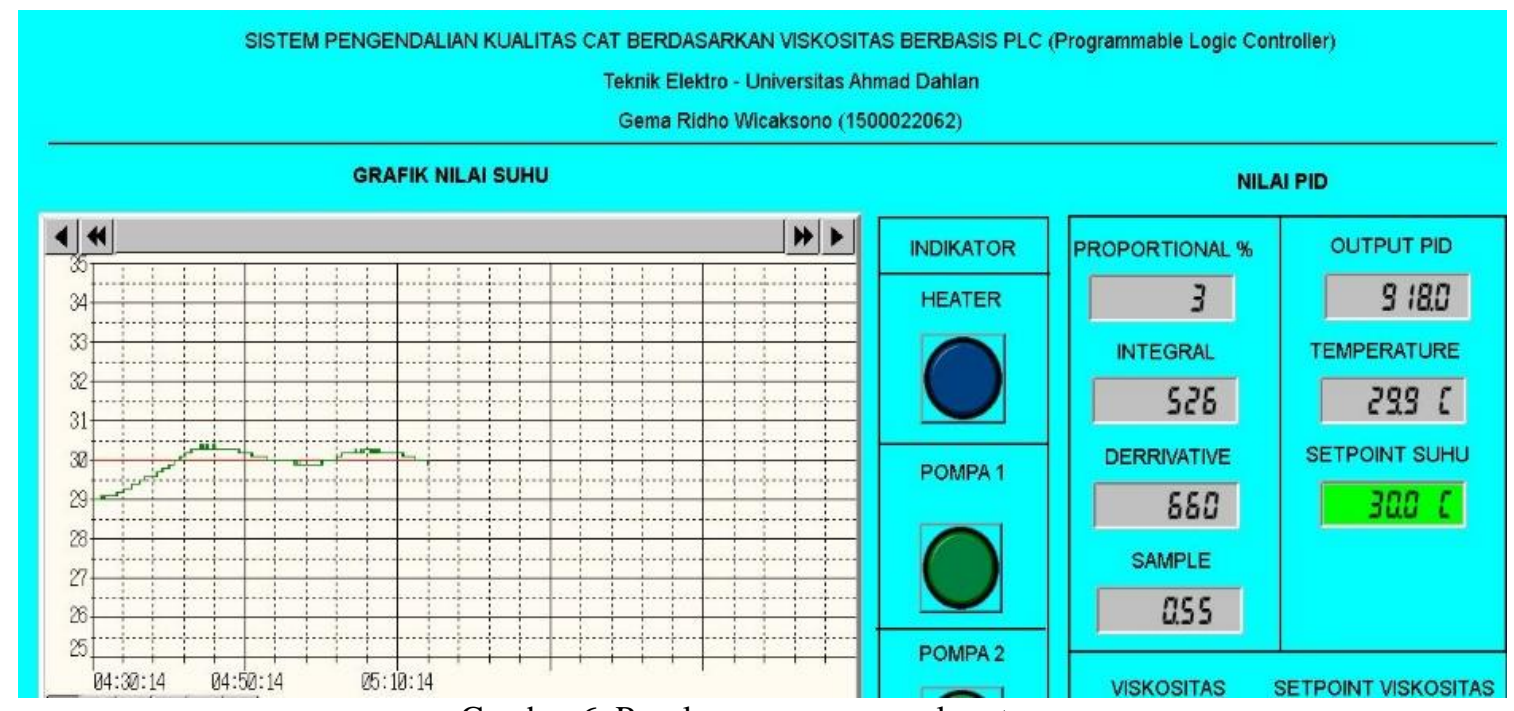

Gambar 6. Penalaan secara manual pertama

Pengujian proses tuning kedua dilakukan dengan setpoint $30^{\circ} \mathrm{C}$ dengan memberi nilai sampling $=0,5 \mathrm{~s}$. Proses penalaan dengan nilai Proportional Band $(\mathrm{PB})=0,2 \% ;$ Integral Constant $(\mathrm{Ti})=452,5 \mathrm{~s}$ dan Derrivative 
Constant $(\mathrm{TD})=66,6 \mathrm{~s}$. Maka didapatkan nilai Rise Time $(\mathrm{TR})=22$ menit; Peak Time $(\mathrm{TP})=24$ menit ; dengan nilai max overshoot $=0,45^{\circ} \mathrm{C}$. Hasil penalaan secara autotuning ditunjukkan Gambar 7 .

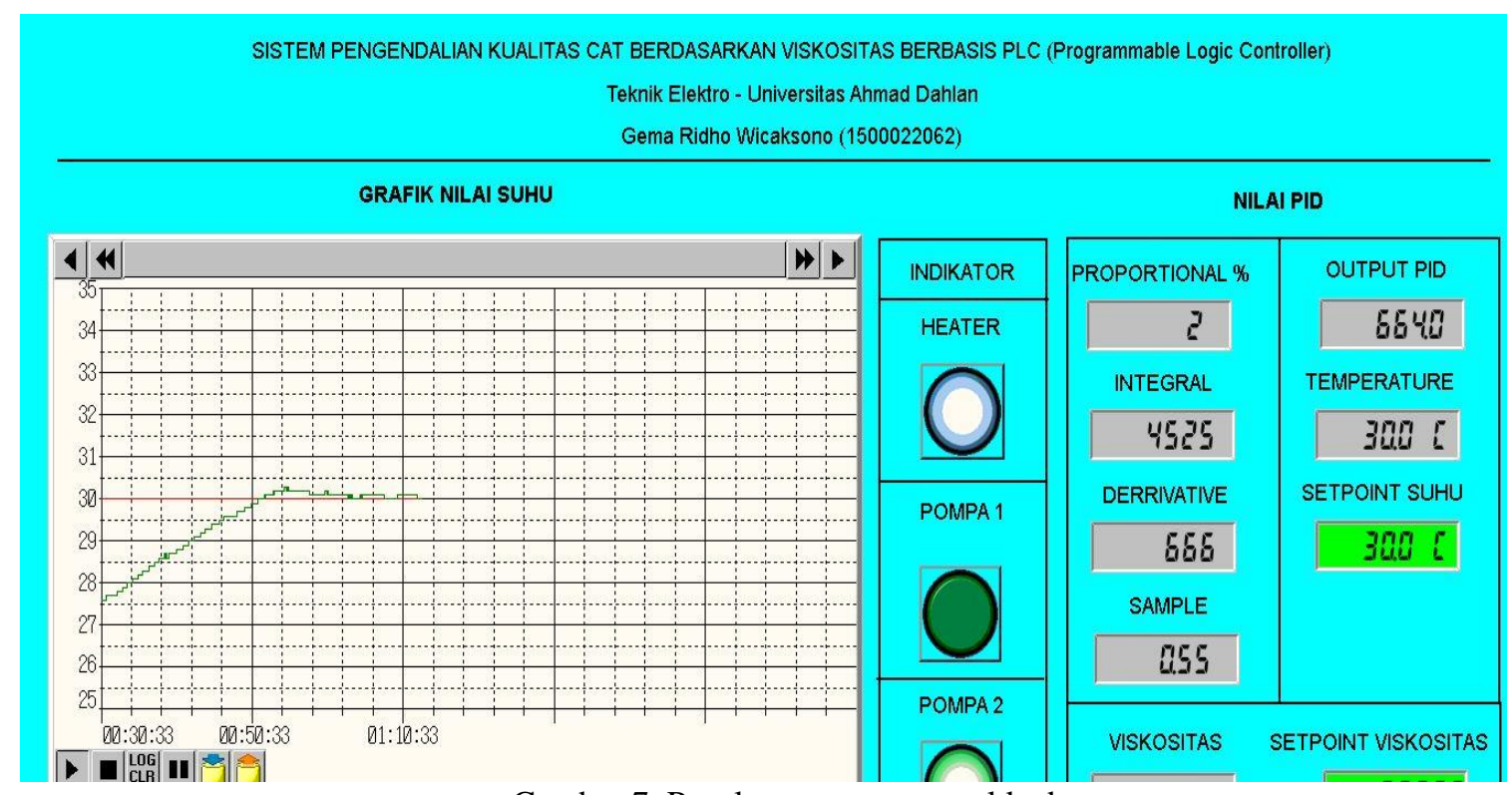

Gambar 7. Penalaan secara manual kedua

Pengujian proses tuning pertama dilakukan dengan setpoint $30^{\circ} \mathrm{C}$ dengan memberi nilai sampling $=0,5 \mathrm{~s}$. Proses penalaan dengan nilai Proportional Band $(\mathrm{PB})=0.3 \%$; Integral Constant $(\mathrm{Ti})=52,7 \mathrm{~s}$ dan Derrivative Constant $(\mathrm{TD})=66 \mathrm{~s}$. Maka didapatkan nilai Rise Time $(\mathrm{TR})=8$ menit; Peak Time $(\mathrm{TP})=12$ menit ; dengan nilai max overshoot $=0,3{ }^{\circ} \mathrm{C}$. Hasil penalaan secara autotuning ditunjukkan Gambar 8 .

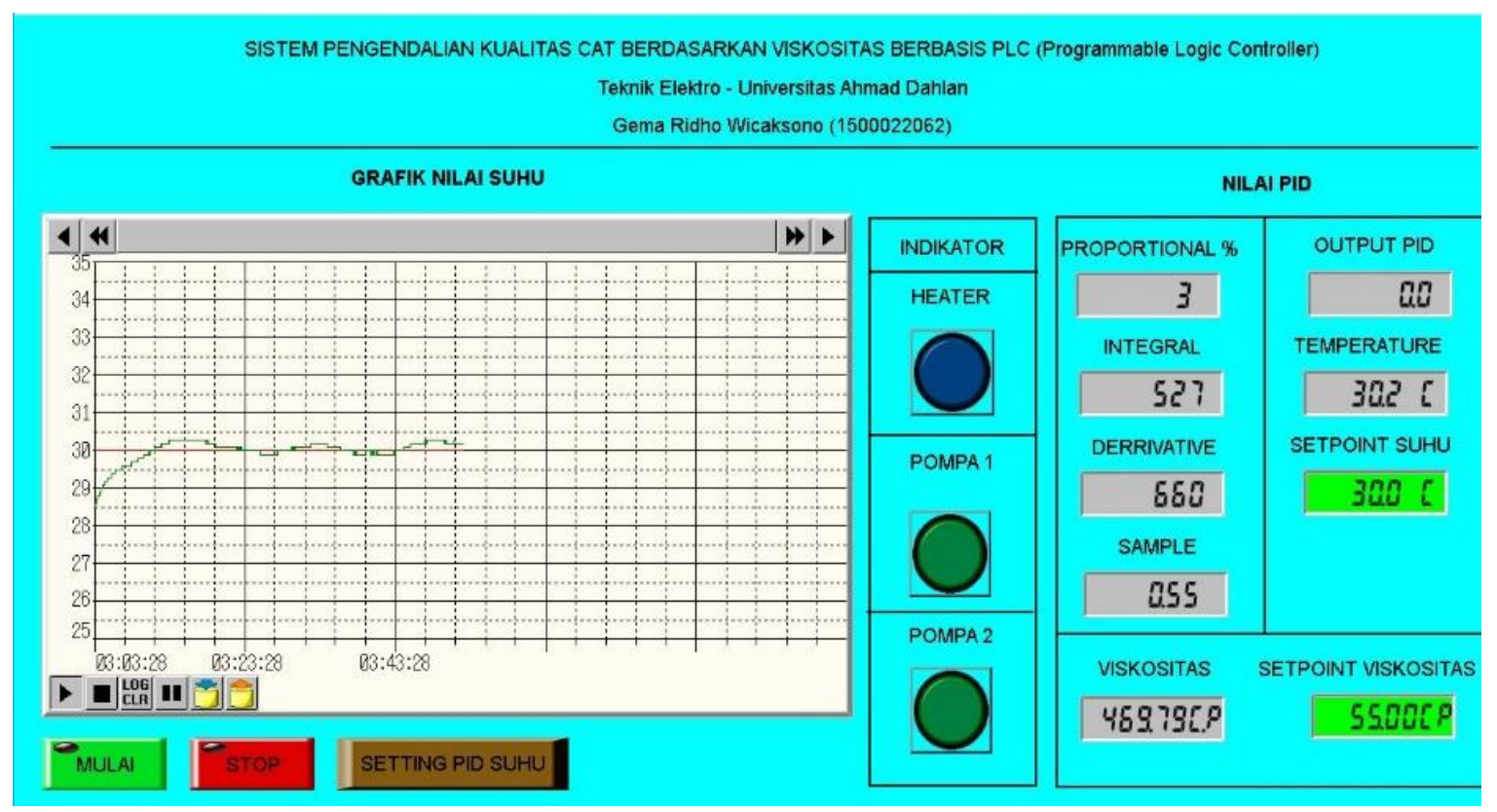

Gambar 8. Penalaan secara manual ketiga

Berdasarkan percobaan PID melalui tuning ataupun autotuning didapatkan respon terbaik dengan nilai Proportional Band $(\mathrm{PB})=0,2 \%$; Integral Constant $(\mathrm{Ti})=452,5 \mathrm{~s}$ dan Derrivative Constant $(\mathrm{TD})=66,6 \mathrm{~s}$. Nilai tersebut baik dikarenakan memiliki nilai koreksi yang kecil.

\subsubsection{Pengujian Viskositas}

Sebelum pengujian pembacaan viskositas cat, sistem pembacaan harus dikalibrasi dengan nilai baku suatu cairan. Hasil uji coba percobaan didapatkan hasil pada Tabel 5 
Tabel 5. Proses kalibrasi pembacaan nilai viskositas

\begin{tabular}{ccccc}
\hline No & Bahan & $\begin{array}{c}\text { Viskositas terbaca } \\
\text { (centiPoise) }\end{array}$ & $\begin{array}{c}\text { Viskositas baku } \\
\text { (centiPoise) }\end{array}$ & Akurasi \\
\hline 1 & Santan Kara & 7,40 & 3,790 & $51 \%$ \\
\hline 2 & Alkohol & 7,76 & 14,7 & $52,78 \%$ \\
\hline 3 & Air biasa & 7,94 & 7,96 & $99,7 \%$ \\
\hline & Akurasi rerata & & & $67,82 \%$ \\
\hline
\end{tabular}

Pengujian dilakukan dengan bahan cat minyak merk INDACO dan Thinner kadar 5\%. Pengujian dilakukan dengan melakukan beberapa uji coba membaca viskositas dari keempat sampel, kemudian dicari nilai mean. Hasil Pengujian ditunjukkan Pada Tabel 6.

Tabel 6. Hasil uji coba

\begin{tabular}{ccc}
\hline No & Bahan & Viskositas (cP) \\
\hline 1 & Cat +thinner 5\% & 75,2 \\
\hline 2 & Cat +thinner 5\% & 76,7 \\
\hline 3 & Cat +thinner 5\% & 78,2 \\
\hline 4 & Cat +thinner 5\% & 76,7 \\
\hline & Rerata & 76,2 \\
\hline
\end{tabular}

Tabel 6 menunjukkan bahwa tingkat akurasi sistem adalah 67,8\% sedangkan Tabel 5 menunjukkan nilai viskositas setpoint yaitu $76,2 \mathrm{cP}$

\section{KESIMPULAN}

Penelitian ini berhasil melakukan pengendalian suhu $30^{\circ} \mathrm{C}$ menggunakan metode PID secara manual ataupun autotuning dengan respon terbaik pada nilai Proportional Band $(\mathrm{PB})=0,2 \%$; Integral Constant $(\mathrm{Ti})=452,5 \mathrm{~s}$ dan Derrivative Constant $(\mathrm{TD})=66,6 \mathrm{~s}$. Penelitian ini berhasil membuat purwarupa pengaduk cat dengan mengendalikan viskositasnya, tetapi dengan tingkat akurasi 67,82 \% HMI dapat menampilkan nilai suhu dan viskositas yang terkoneksi dengan PLC.

\section{UCAPAN TERIMA KASIH}

Ucapan terima kasih kepada editor dan reviewer atas segala saran, masukan dan telah membantu dalam proses penerbitan naskah. Ucapan terima kasih juga ditujukan kepada pihak-pihak yang telah mendukung penelitian dan memberikan bantuan moral dan material.

\section{REFERENSI}

[1] N. J. Habibie and S. Anwar, "Pengaruh Perbandingan Campuran Cat dengan Thinner Terhadap Kualitas Hasil Pengecatan," JTM, vol. 2, no. 3, pp. 97-104, 2014. Online

[2] F. I. Permana and S. Anwar, "Pengaruh kualitas Thinner pada Campuran Cat Terhadap Hasil Pengecatan," JTM, vol. 3, no. 2, pp. 53-61, 2014. Online

[3] P. M. Khadafi, "Alat Ukur Viskositas Cairan Menggunakan Metode Silinder Konsentris Berputar," F. MIPA UI, 2013.

[4] A. Suwandi, "Peningkatan Kualitas untuk Meminimasi Cacat Produk Cat Polyurethane dengan Metode Taguchi," Jurnal Inovisi, vol. 12, no. 02, pp. 55-71, 2016. Online

[5] OMRON, "Instructions Reference Manual PLC Omron," 2014. Online

[6] R. D. Puriyanto, S. A. Akbar, and A. Aktawan, "Desain Sistem Biodiesel Berbasis PLC Berdasarkan Diagram Keadaan," J. Ilm. Tek. Elektro Komput. dan Inform., vol. 4, no. 2, p. 1, 2019. DOI: https://doi.org/10.26555/jiteki.v4i2.12051

[7] OMRON, “CP1E CPU Unit Hardware User Manual,” 2016. Online

[8] M. F. Al Andzar and R. D. Puriyanto, "PID Control for Temperature and Motor Speed Based on PLC", Sig.Img.Proc.Lett, vol. 1, no. 1, pp. 7-13, Mar. 2019. DOI: https://doi.org/10.31763/simple.v1i1.150

[9] A. Junaidi and W. S. Aji, "Sistem Pengontrol Suhu Ruangan dengan Algoritma PID Menggunakan PLC Omron CP1e-NA20DR-A," J. Ilm. Tek. Elektro Komput. dan Inform., vol. 3, no. 2, p. 47, 2017. DOI: https://doi.org/10.26555/jiteki.v3i2.7069 


\section{BIOGRAFI PENULIS}

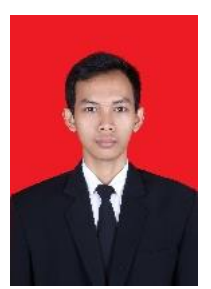

Gema Ridho Wicaksono adalah mahasiswa Program Studi Teknik Elektro, Fakultas Teknologi Industri Universitas Ahmad Dahlan, Yogyakarta yang telah menyelesaikan pendidikan sarjana pada program studi tersebut.

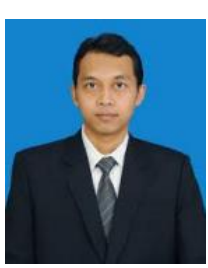

Riky Dwi Puriyanto adalah Dosen di Program Studi Teknik Elektro, Fakultas Teknologi Industri, Universitas Ahmad Dahlan, Yogyakarta. 